China Perspectives

$2017 / 3$ | 2017

Varia

\title{
The China Factor in Taiwan's Media
}

Outsourcing Chinese Censorship Abroad

\section{Huang Jaw-Nian}

\section{(2) OpenEdition \\ Journals}

Electronic version

URL: http://journals.openedition.org/chinaperspectives/7388

ISSN: 1996-4617

\section{Publisher}

Centre d'étude français sur la Chine contemporaine

\section{Printed version}

Date of publication: 1 September 2017

Number of pages: $27-36$

ISSN: 2070-3449

\section{Electronic reference}

Huang Jaw-Nian, «The China Factor in Taiwan's Media », China Perspectives [Online], 2017/3 | 2017,

Online since 01 September 2018, connection on 28 October 2019. URL : http://

journals.openedition.org/chinaperspectives/7388

(C) All rights reserved 


\title{
The China Factor
}

\section{in Taiwan's Media}

\author{
Outsourcing Chinese Censorship Abroad
}

HUANG IAW-NIAN

\begin{abstract}
To investigate how the Chinese government extends its influence to manipulate extra-jurisdictional media, this case study investigates Taiwan's experience. It suggests that as Taiwanese media companies become embedded in the Chinese capital, advertising, and circulation markets, the Chinese authorities increase their ability to co-opt them with various economic incentives and threats, leading to self-censorship and biased news in favour of China. Using process tracing as the principal method, and archives, interviews, and secondary literature as principal data sources, the study supports the transferability of the "commercialisation of censorship" beyond China. Liberal states around China must design institutions protecting the media from inappropriate intervention by both domestic and foreign political and economic forces.
\end{abstract}

\section{KEYWORDS: China Factor, Commercialisation of Censorship, Media, Self-censorship, Taiwan.}

\section{Introduction}

A ccompanying the trend of China's economic rise, concern has been growing in the international community about the potential impact of China's authoritarian regime on human rights and democracy in neighbouring societies and even globally (Gat 2007; Diamond 2009; Kurlantzick and Link 2009; Ambrosio 2010; Chang Mau-Kuei 2011; Wu 2012; Pillsbury 2015; Nathan 2015). Its impact on the media's liberal practices is one of the issues attracting the most attention (Sciutto 1996; Link 2002; Ma 2007; Cook 2013; Hsu 2014; Kawakami 2015). In this regard, the Taiwanese experience warrants attention. After two decades of improvement in the post-democratisation era, Taiwan's media freedom seems to have been eroding since the late 2000s, when Taiwan began engaging in closer economic cooperation with China. According to Freedom House and Reporters Without Borders, Taiwan's press freedom shows a deteriorating trend from 2008 to the present (see Figures 1 and 2). (1) In particular, Freedom House fears the "potential direct or indirect influence of the Chinese government on free expression in Taiwan" when the "commercial ties between Taiwan and mainland China deepened in 2010 with the signing of the Economic Cooperation Framework Agreement." (2) Amnesty International also notes that the "concentration of ownership of media outlets raised concerns about freedom of expression and editorial independence" in Taiwan. ${ }^{(3)}$ These phenomena motivated this paper's main inquiry: Through what mechanisms does China extend its authoritarian influence into the extra-jurisdictional media?

Existing literature rarely suggests a theoretical framework systematising the mechanisms by which the Chinese government exerts its influence on other countries' media. Some studies explore how China encouraged other countries, especially authoritarian and developing states, to adopt the socalled "China model" of authoritarian capitalism. Beijing's general tactics include offering diplomatic support at the United Nations, building new in- ternational institutions such as the Shanghai Cooperation Organization, providing economic aid without human rights obligations, establishing Confucius Institutes globally, and expanding Chinese official media and other pro-Beijing media abroad (Kurlantzick and Link 2009; Kurlantzick 2013; Pillsbury 2015; Nathan 2015). These studies enhance understanding of the general dynamics of the China model's transnational diffusion. However, in regarding the media as only one of Beijing's comprehensive instruments to exercise influence overseas, they identify few specific mechanisms for China's influence over media abroad.

Other studies examine how the Chinese government has controlled the media within its own sovereign territory. In China, the Chinese Communist Party (CCP) enforces administrative censorship on the media with political and legal penalties. It has also mastered the media through the "commercialisation of censorship," in which censorship is "outsourced" to private media companies by threatening them with economic repercussions. Both political and economic threats have generated "fear-induced self-censorship" in China (Link 2002; Kurlantzick and Link 2009). A similar phenomenon has occurred in Hong Kong. Without the legal right to directly intervene in Hong Kong's media, the Chinese authorities have still achieved a similar pattern of self-censorship in Hong Kong through physical assaults, cyberattacks, threatening lost advertising, and transferring media ownership to pro-Beijing figures (Sciutto 1996; Ma 2007; Cook 2013). These studies improve understanding of the mechanisms through which the CCP manipu-

1. Freedom House, "Detailed Data and Sub-Scores 1980-2016," 2016, https://freedomhouse.org/report-types/freedom-press (accessed on 7 March 2017); Reporters Without Borders, "World Press Freedom Index 2016," 2016, https://rsf.org/en/ranking (accessed on 7 March 2017).

2. Freedom House, "Taiwan: Freedom of the Press 2010," 2010, http://www.freedomhouse.org/report/freedom-press/2010/taiwan (accessed on 7 March 2017); Freedom House, "Taiwan: Freedom of the Press 2011," 2011, http://www.freedomhouse.org/report/freedom-press/2011/taiwan (accessed on 7 March 2017)

3. Amnesty International, "Amnesty International Report 2013: The State of the World's Human Rights," 22 May 2013, http://www.amnestyusa.org/research/reports/state-of-the-world-2013 (accessed on 7 March 2017). 
Figure 1 -Taiwan's press freedom scores by Freedom House

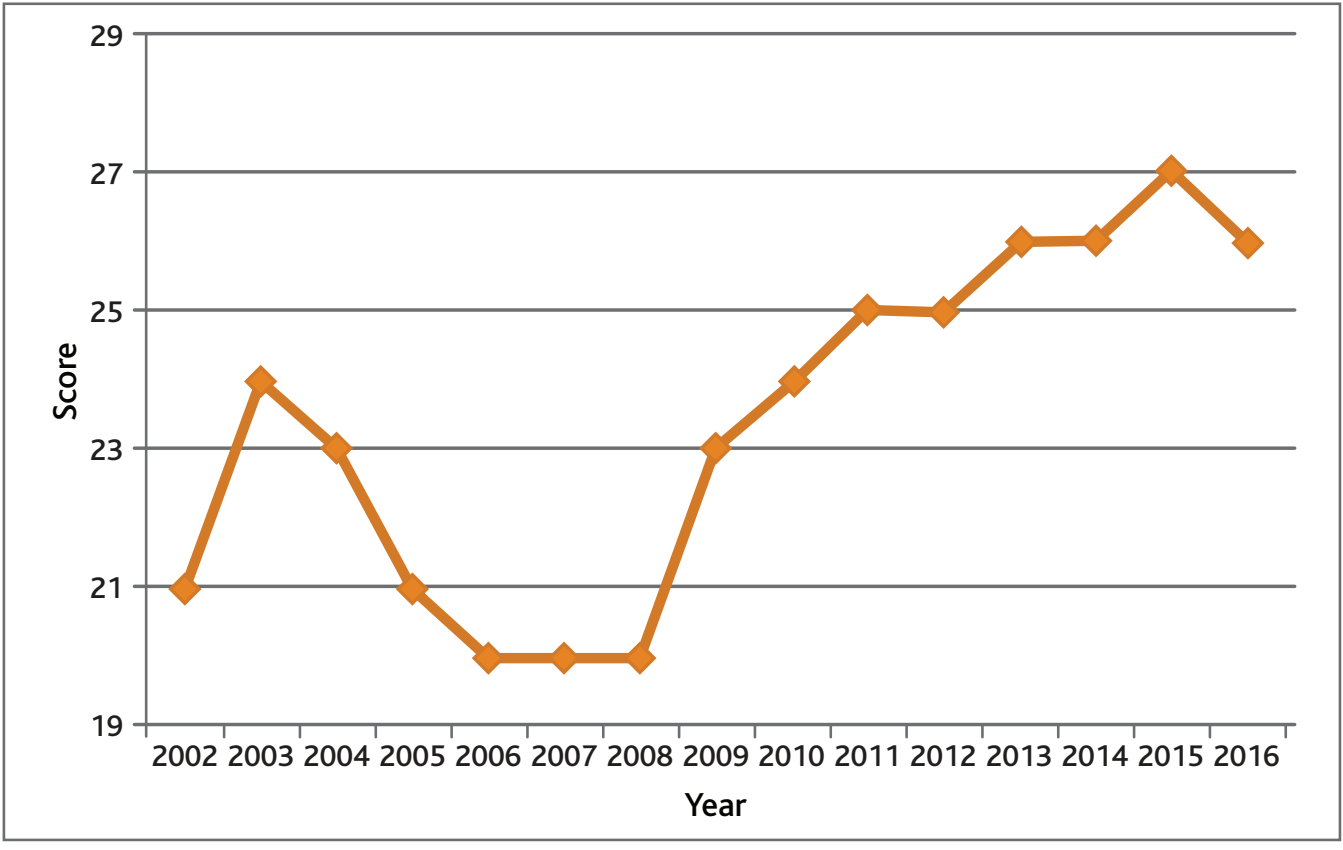

Note: The higher the score, the lower the level of press freedom. Source: Freedom House, "Detailed Data and Sub-Scores 1980-2016," 2016, https://freedomhouse.org/report-types/freedom-press (accessed on 7 March 2017).

lates the domestic media. They may also inspire our thinking about how China affects media abroad. However, it is doubtful whether the mechanisms operating within China could apply to Taiwan and other countries de facto independent of China.

Further studies investigate how the Chinese government influences the Taiwanese media. Based on experiences in Taiwan, the approaches Beijing has generally adopted to urge Taiwanese media to exercise self-censorship have been identified, including offering them embedded advertisements, buying the copyrights of TV programs from them, encouraging pro-Beijing businesspeople to purchase media in Taiwan, and pressuring Taiwanese journalists and media owners, among others (Cook 2013; Hsu 2014; Kawakami 2015). These studies offer a sufficiently detailed explanation of China's influence mechanisms on the Taiwanese media. However, they do not provide a theoretical framework potentially transferrable and applicable to other countries. This is because, from the perspective of the "ladder of abstraction" (Sartori 1970), the mechanisms identified by these studies remain largely factual and require further abstraction to the level of theory.

To fill the aforementioned gaps, this paper proposes a theoretical framework to systematise the mechanisms through which the Chinese government extends its authoritarian influence on the extra-jurisdictional media. A case study on Taiwan's experience will then be conducted to examine the effectiveness of the proposed theory.

\section{The transnational diffusion of Chinese censorship: A theoretical framework}

By integrating Kurlantzick and Link's model of the "commercialisation of censorship" with Wu Jieh-min's model of the "China factor" influence mechanism, this paper constructs a theoretical framework systematising the mechanisms through which the Chinese government spreads its censorship extra-territorially. According to Kurlantzick and Link, the "commercialisation of censorship" is a modern authoritarian model of media control created by the CCP early in the twentyfirst century. In this model, censorship in China was not only implemented through traditional political and legal penalties but has also been largely "outsourced" to private media companies by threatening them with economic repercussions, such as losing subsidies and advertisements. Fearing political and economic punishment, China's media tend to exercise self-censorship on topics deemed sensitive to the Chinese authorities (Kurlantzick and Link 2009). According to Wu Jieh-min, the "China factor" is the process by which the Chinese government exerts political influence on other countries by absorbing them into its sphere of economic influence. In particular, Beijing generally creates a structure in which the target country becomes economically dependent on China, establishes government-business networks with the country, develops a group of local collaborators there by offering privileges and special interests, and finally employs these collaborators to achieve Beijing's intended goals in local society (Wu 2016).

Based on these two models, this paper's theoretical framework identifies three steps by which the Chinese government "outsources" its censorship to private media companies abroad. These three steps correspond with three levels of analysis, comprising the international, sectoral, and corporate levels. Relevant analytical categories and their dynamic relations are discussed below (see Figure 3).

The first step is to create an asymmetric economic structure at the international level, making the target country economically dependent on China. As a rising regional hegemon, China seeks to establish an alternative international order in the region and even globally to compete with the existing American hegemony. As the "China factor" model suggests, economic influence is the fundamental means by which Beijing exerts political influence and fulfils its political goals in other countries. To spread its ideas and practices abroad, China thus endeavours to maintain its economic advantage over other countries. Following the same logic, the transnational diffusion of Chinese censorship must originate in such economic domination.

The second step is to co-opt media capitalists at the sectoral level to become Beijing's local collaborators in the target country. While the "China factor" model indicates local collaboration as an important mechanism realising China's political goals abroad, the "commercialisation of censorship" model suggests that economic incentives and threats have become major instruments for Chinese censorship to be "outsourced" to private media companies. Taken together, Beijing typically incorporates local media capitalists as its collaborators to exercise Chinese censorship in the target country, either by providing them with financial resources in the Chinese circulation, advertising, and capital markets, or by threatening to cease offering such interests. 
The third step is to implement and routinize external-oriented selfcensorship at the corporate level in the target country. Assisted by local media capitalists, the corporate and market structures of the target country's media tend to accommodate Beijing's mass communication policies. Such structural changes may finally encourage journalists in the target country to routinize selfcensorship in favour of Beijing in the news editing process.

Based on this proposed theoretical framework, this paper argues that a media company outside China will exercise self-censorship on Chinese-sensitive topics when it becomes commercially tied with the Chinese market. To examine the proposed theory, a case study will be conducted on Taiwan's experience. Process tracing is used as the study's principal method, as it is competent to divide the theoretical link between cause and effect into smaller steps, seek empirical evidence for each step, and confirm the effectiveness of the proposed causal mechanism (George and Bennett 2005). Several Taiwanese media companies are selected as the subjects, including the Want Want-China Times Media Group, United Daily News (UDN), Sanlih E-Television (SET), and Formosa Television (FTV). Applying the principles of purposive and quota sampling, the former two and the latter two are respectively selected to represent pro-Chinese unification and pro-Taiwanese identity media in Taiwan. The experiences of some other media companies are also discussed in the case study. Archives, interviews, and secondary literature gathered through fieldwork in Taiwan are the main sources of research data. The interview data are based on semi-structured interviews with 22 media journalists (including media managers, journalists, non-governmental organisation activists, and government officials) in Taiwan during the first half of 2014 .

\section{Reinforcing an economic dependence structure across the Taiwan Strait}

From no later than the 2000s, Taiwan has become increasingly economically dependent on China. Taiwan signed a series of free trade agreements with five Latin American diplomatic allies (Panama, Nicaragua, El Salvador, Honduras, and Guatemala) in the 2000s, with China in 2010, with New Zealand in 2013, and with Singapore in 2013. Taiwan also signed an investment agreement with Japan in 2011 and continued negotiating with the US over the Trade and Investment Framework Agreement. Among these countries, China developed the strongest economic influence over Taiwan, replacing the US and Japan as Taiwan's largest trade partner from 2005 until the present. As Figure 4 shows, China was responsible for $22.67 \%$ of Taiwan's total trade in 2015 , while the US and Japan respectively accounted for $11.92 \%$ and $11.39 \%$, and Singapore, New Zealand, and the five Latin American diplomatic allies represented only $4.79 \%, 0.25 \%$, and $0.16 \%$ respec- tively. ${ }^{(4)}$ China also replaced the US as Taiwan's largest export market in 2004. ${ }^{(5)}$ As Figure 5 shows, in 2000, the US accounted for $23.42 \%$ of Taiwanese annual exports, whereas China was only responsible for $2.89 \%$. However, as Taiwanese annual exports to the US dropped to respectively represent $14.67 \%, 11.46 \%$, and $12.21 \%$ of total Taiwanese annual exports in 2005, 2010, and 2015, Taiwanese annual exports to China rapidly rose to $21.99 \%, 28.02 \%$, and $25.40 \%$ of the corresponding totals. Moreover, the latest statistics show that while exports to the US decreased to $11.96 \%$ in 2016 , exports to China grew to $26.36 \%$. ${ }^{(6)}$ China has served as Taiwan's main source of trade surplus. In terms of capital, Taiwan's relationship with China has intensified. To illustrate, since the Taiwanese government lifted its restriction on Taiwanese investment in China in 1991, China has gradually become the most popular location for Taiwanese people to invest. As Table 1 shows, Taiwanese investments in China steadily rose from 1991 and even surpassed all Taiwanese outward investments in other foreign countries from 2002. Though there have been signs of Taiwanese businesses starting to transfer investments from China to other countries since 2015, China still abstracted more than twice as many investments as Japan, Taiwan's second largest investment target, in 2016. (7) Similarly, after the Taiwanese government incrementally loosened its restrictions on Chinese investments in certain Taiwanese industries starting from 2009, increasing direct investment flows from China to Taiwan have appeared. ${ }^{(8)}$

4. The Taiwan Bureau of Foreign Trade, "Trade Statistics \#FSC3040: Ranking of Total Trade, Exports, and Imports for Taiwan's Trading Partners," 2016, http://cus93.trade.gov.tw/FSCI/ (accessed on 7 March 2017).

5. Ibid.

6. Taiwan Economic Data Center, "AREMOS Taiwan Economic Statistics Dataset," 2016, http://net.aremos.org.tw/ (accessed on 7 March 2017); The Taiwan Ministry of Finance, "Customs Administration Statistics Dataset," 2017, https://portal.sw.nat.gov.tw/APGA/GA01 (accessed on 7 March 2017).

7. The Taiwan Investment Commission, "Statistics Monthly Report (January 2017)," 2017, http://www.moeaic.gov.tw/news.view?do=data\&id=1135\&lang=ch\&type=business_ann (accessed on 7 March 2017).

8. Ibid. 


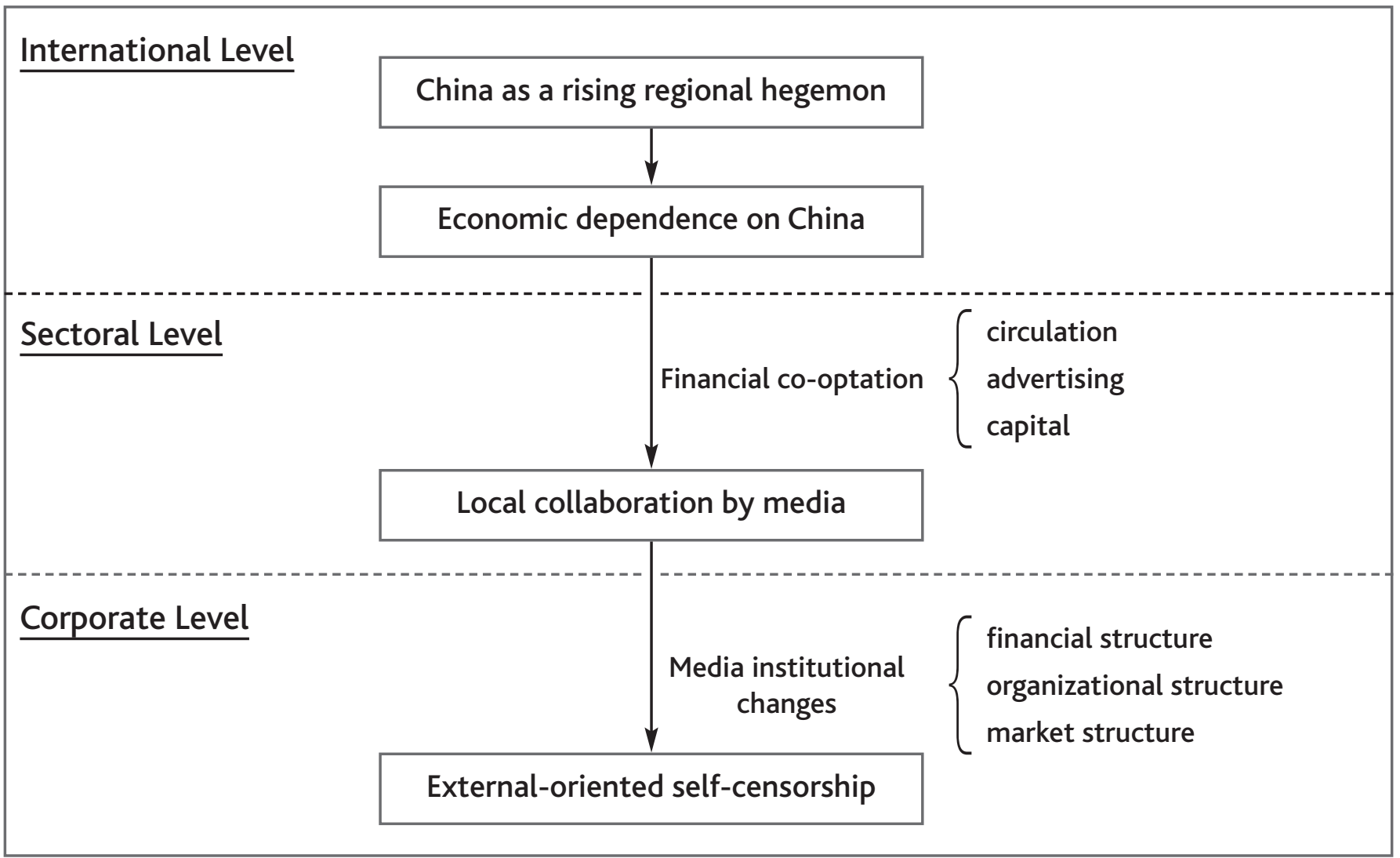

China was eager to reinforce this structure of economic dependence by incorporating Taiwan into its international economic order. As a rising regional hegemon, China has sought to counter American hegemony to establish an alternative world order since the 2000s. In 2003, the phrase "peaceful rise" (heping jueqi) was proposed by the Chinese government to describe its national development blueprint for the twenty-first century. The government later replaced "rise" with "development" in 2004, to soften the perception that China would threaten the established world order. However, "peaceful development" (heping fazhan) was understood as China's new national development strategy, which sought to internally establish a series of Chinese-style "harmonious" political, economic, and social institutions, and externally establish an alternative world order by challenging the hegemonic status of the US (Shiau 2004, p. 24). Regarding regional economic order, China did not embrace the prospect of open-regionalism advocated by the US and other Asia-Pacific developed countries, involving strengthening cooperation between East Asia and other regions and realising financial and trade liberalisation. Instead, China undertook to promote another version of regionalism in which East Asian states cooperated with one another to confront US-led open-regionalism and globalisation (hiau 2004 pp. 10-11). As part of the CCP's unification strategy towards Taiwan, Beijing has also long attempted to "promote unification by economic means" (yi jing cu tong), that is, to facilitate cross-Strait political reconciliation and ultimate reunification by intensifying China's economic and trade ties with Taiwan, although Beijing has never abandoned the possibility of unifying Taiwan by force. Therefore, to isolate Taiwan from international connections and absorb Taiwan into its international economic order, China prevented Taiwan from signing FTAs with Taiwan's important trading partners throughout the 2000s, and encouraged Taiwan to sign the Economic Cooperation
Framework Agreement (ECFA) with China in 2010 by surrendering part of its own profits (Tung 2011, p. 109, 112). ${ }^{(9)}$

Alongside expanding economic ties between Taiwan and China, an increasing number of government-business networks have been constituted across the Taiwan Strait since the 2000s, such as the Boao Forum for Asia, the Cross-Strait Economic and Cultural Forum, the Straits Forum, the CrossStrait CEO Summit, and national and local Taiwanese business associations in China. Through these networks, Taiwanese entrepreneurs seeking to do business in China have opportunities to pursue economic benefits from the Chinese government; meanwhile, Chinese authorities with regulatory powers over economic activities in China also gain opportunities to secure Taiwanese capitalists' loyalty by offering privileges and special favours (Wu $2015,2016)$. The cross-Strait media sector is no exception. To strengthen China's media warfare against Taiwan, former Chinese President Hu Jintao announced "Entering the Island, Entering the Household, and Entering the Mind" (rudao, ruhu, ruxin) as a new principle of the CCP's unification propaganda towards Taiwan at the Central People's Broadcasting Station's $50^{\text {th }}$ anniversary of its first broadcast to Taiwan on 12 August 2004. For this purpose, Beijing has endeavoured to narrow Taiwanese media's access to international institutions and events, and to actively create communication networks with Taiwanese media organisations and officials (Cook 2013, p. 30, 32). For instance, Taiwanese media owners and professionals are regularly invited to participate in government-hosted media forums in China, such as the Straits Forums. Directed by the Straits Exchange Foundation of Taiwan, Taiwanese media shareholders, editors, and managers organised their

9. It remained controversial whether China really surrendered part of its own profits to Taiwan in negotiating the ECFA. While the Chinese authorities maintained this position, the Taiwanese government did not officially acknowledge it. 
first "Media Executives Delegation" to China in October 2009, during which they met Wang Yi, Director of the State Council Taiwan Affairs Office of China, and Chen Yunlin, Chairman of the Association for Relations Across the Taiwan Straits of China. Upon the Chinese authorities' request, some Taiwanese media officials were even selected to attend "closed-door meetings" in Beijing to be educated on the Chinese central government's guidelines for managing public opinion (Lee 2014, pp. 133, 135).

\section{Co-opting media capitalists as local collaborators in Taiwan}

Alongside Taiwan's increasing economic dependence on China, Taiwanese media companies became increasingly commercially tied to the Chinese market from the 2000s onward. An academic survey conducted in the mid-2000s found that $38.4 \%$ of Taiwanese media companies had expanded their businesses overseas and over $90 \%$ were doing business in China. While the overseas business volume represented an average of $34 \%$ of a media company's total business volume, the business volume in China generally accounted for $40 \%$ of the total overseas business volume. China was therefore the most important overseas market. Furthermore, $30 \%$ of those who had not yet entered the Chinese market expressed their expectation to do so shortly (Chen 2006, pp. 57-58, 60, 68). Taiwanese media companies especially craved financial resources from China to improve their finances when advertising revenues from Taiwanese private enterprises declined due to the 2008 financial crisis, compounded by lost revenues following the prohibition of government-sponsored embedded marketing in 2011 (Chung 2012, pp. 67-70).

Under these circumstances, the Chinese government has had more opportunities to co-opt Taiwanese media companies as instruments for its hegemonic and unification propaganda towards Taiwan, by either offering financial resources in the Chinese circulation, advertising, and capital markets, or threatening to deny access to the profitable Chinese market. As an authoritarian regime with strict media censorship, the Chinese government is devoted to preventing its domestic media from covering certain forbidden topics (such as the Tiananmen Incident, Taiwan independence, Tibetan or Xinjiang autonomy, and Falun Cong), and it also endeavours to guide editors and journalists to express views the government favours (such as those stimulating people's identification with the CCP, patriotism, and animosity against external threats) (Kurlantzick and Link 2009). To ensure their corporate interests in China, many Taiwanese media companies, regardless of their positions on the unification-independence issue, have started to cooperate with Beijing's mass communication policies by adjusting their news editing principles according to "hidden rules" (qian gui ze) ${ }^{(10)}$ that favour the Chinese authorities. Generally, Taiwanese media are discouraged from presenting sensitive issues that might annoy the Chinese authorities (consistent with the aforementioned forbidden topics for China's media). Instead, Taiwanese media are encouraged to promote perspectives propagandised by the Chinese government, such as social harmony, crossStrait exchange, mutual understanding, and peaceful development (Cook 2013, pp. 25-26). (11)

\section{Circulation}

Given China's huge circulation market of 1.3 billion people, many Taiwanese media companies have sought to establish offices, circulate newspapers, broadcast TV programs, and provide access to websites there to earn more subscriptions, copyright fees, and advertising revenue (Lee 2014, pp. 133-134). (12) However, the Chinese government explicitly or implicitly requires these companies to conform to Chinese censorship, not only in China but also in Taiwan in exchange for circulation revenue and subsequent advertising income from China. This applied to both print and electronic media. For instance, the two traditional newspapers in Taiwan, the China Times and the UDN, have been striving to distribute their newspapers in China

10. Interview with Lu Dong-Shi, former president of the Taiwan Journalists Association, Taipei, 24 June 2014; interview with Ni Yen-Yuan, former chief editorial writer of the China Times, Taipei, 16 July 2014; interview with Anonymous Interviewee, senior manager of United Daily News Television, 11 July 2014; interview with Anonymous Interviewee, senior editor of SET, 30 July 2014; interview with Feng Sylvia, founder of the Alliance for the Birth of Public Media and former general manager of the Taiwan Public Television Service (PTS), Taipei, 13 August 2014.

11. Interview with Lu Dong-Shi; interview with Ho Jung-hsing, founder and former president of the Taiwan Journalists Association, Taipei, 14 July 2014; interview with Hu Yuan-Hui, former general manager of the Taiwan Television Enterprise and former president of the Central News Agency, Taipei, 25 July 2014

12. Interview with Lu Dong-Shi; interview with Chen Hsiao-yi, president of the Taiwan Journalists Association, Taipei, 27 June 2014; interview with Ho Jung-hsing; interview with Hu Yuan-Hui; interview with Su Tzen-ping, former director of the Government Information Office and former chairman of the Central News Agency, Taipei, 28 July 2014; interview with Lee Chih-Te, senior news reporter of Radio Free Asia, Taipei, 19 August 2014. 
Figure 5 - Percentage of Taiwan's total export volume, 1981-2015

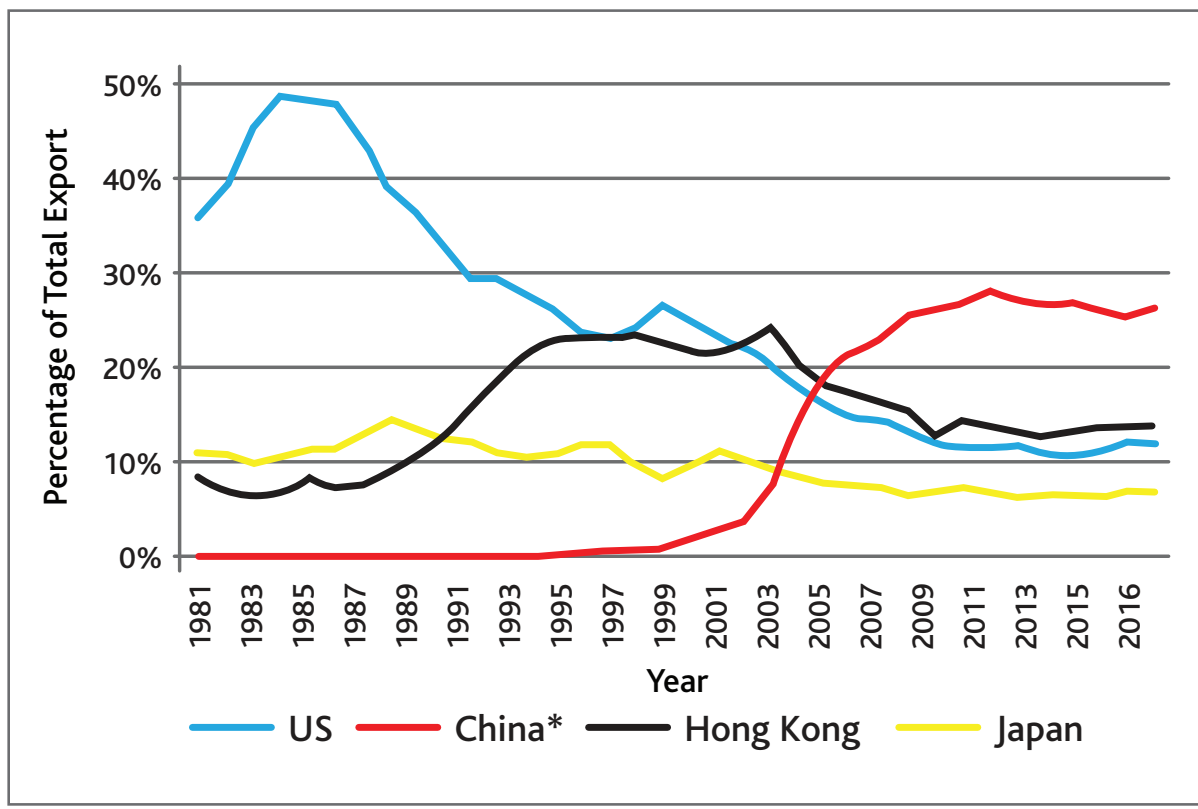

*excludes Hong Kong

Source:Taiwan Economic Data Center, "AREMOS Taiwan Economic Statistics Dataset," 2016, http://net.aremos.org.tw/ (accessed on7 March 2017); The Taiwan Ministry of Finance, "Customs Administration Statistics Dataset," 2017,

https://portal.sw.nat.gov.tw/APGA/GA01.

since the 1990s. The UDN even won the special right to directly print and distribute its newspaper in Dongguan, China on 1 April 2006. ${ }^{(13)}$ For such privileges to be granted by China's State Council Taiwan Affairs Office, both newspapers had to prevent their news reports and commentaries from annoying the Chinese authorities. The UDN even frequently carried embedded advertisements for Chinese local governments in its mainland edition. Despite these privileges, the circulation of both Taiwanese newspapers in China has still been restricted to certain regions, organisations, and people, such as Taiwanese enterprises, foreign businesses, five-star hotels, and academic institutions for Taiwan studies. ${ }^{(14)}$

Regarding television media, there are several examples. According to Hu Yuan-Hui (former General Manager of Taiwan Television Enterprise [TTV]), TTV planned to establish new offices in Beijing and other cities in China in 2001. However, the Chinese government passed a clear message to TTV's management via a TTV reporter: no permit for the new offices would be issued until broadcasting of a TTV program about Falun Gong was halted. The permit's issuance was continually delayed while the Falun Gong program was broadcast; it was only issued when the program was terminated as originally scheduled by TTV. ${ }^{(15)}$ Due to this incident, most Taiwanese media planning to enter the Chinese market became reluctant to produce news reports and TV programs about Falun Gong. ${ }^{(16)}$

Even pro-Taiwanese identity television companies, such as FTV and SET, strive to sell the copyrights of their TV programs and dramas to China for additional financial income (Cook 2013, pp. 32-33; Hsu 2014, pp. 526-528; Kawakami 2015 , p. 18), (17) especially after the decline of their advertising revenues due to the 2008 financial crisis and the 2011 prohibition of government-sponsored embedded marketing (Chung 2012, pp. 67-70). In particular, FTV sought cooperation with state broadcaster China Central Television to have some Taiwanese-language soap operas dubbed into Mandarin Chinese and broadcasted in China. Probably to smooth such business transaction, FTV tended to avoid broadcasting TV programs on topics deemed sensitive to Beijing. For instance, as the founder of FTV and a Central Standing Committee member of the Democratic Progressive Party (DPP), Chai Trong-rong declined a mid2009 proposal in the DPP Central Standing Committee for FTV to purchase and broadcast the film "The Ten Conditions of Love," a documentary about Rebiya Kadeer, the Xinjiang independence movement's spiritual leader (Hsu 2014). ${ }^{(18)}$

Similarly, SET has been striving to broadcast their TV dramas in China since 2008. Its president, Chang Jung-hua, even replaced the term "Taiwanese drama" (tai ju) with the SET-created term "Chinese drama" (hua ju) in December 2011 to facilitate SET's business in China. However, China's National Broadcasting Headquarters, an institution holding power to approve the broadcasting of the dramas from abroad, hinted that SET should axe "Big Talk News" (dahua xinwen), a popular pro-Taiwanese identity, anti-Beijing political talk show in Taiwan, to smoothen its business in China. Consequently, Big Talk News was finally cancelled in May 2012, under pressure from the Chines authorities (Chung 2012, pp. 27, 33-34, 39, 52, 78). ${ }^{(19)}$

A similar phenomenon struck internet media. According to a media survey conducted from 12 January to 1 April 2015, the amount of Taiwanese media web content blocked in China basically mirrored the level of the media's friendliness/animosity towards Beijing. For instance, while the websites of the pro-Taiwanese identity Liberty Times and the anti-Communist Apple Daily were respectively $95 \%$ and $92 \%$ blocked in China, those of the proChinese unification newspapers UDN and China Times, for example, were respectively $67 \%$ and $0 \%$ blocked. (20) Taiwanese media apparently needed to avoid using keywords deemed sensitive in China to ensure a high level of traffic flow in Chinese cyberspace and benefit from the accompanying advertising revenues. ${ }^{(21)}$

\section{Advertising}

In addition to the circulation market, the Chinese government also incorporated Taiwanese media companies into the advertising market. From the

13. China Times, "The United Daily's Privilege to Have Newspapers Printed in Mainland China," Chin Times, 17 November 2012.

14. Interview with Su Tzen-ping.

15. Interview with Hu Yuan-Hui.

16. Interview with Anonymous Interviewee, senior manager of the Want Want-China Times Group, Taipei, 13 June 2014.

17. Interview with Anonymous Interviewee, former senior manager of FTV, Taipei, 11 July 2014.

18. Interview with Anonymous Interviewee, former senior manager of FTV, Taipei, 11 July 2014

19. Shu-fang Ji, "Shutting off the Big Talk News for Entering the Chinese Market?," Wealth Magazine, 25 May 2012; Hsiao-Tzu Sun, "Cheng Hung-Yi Says Goodbye to the Big Talk News," The Journalist, 24 May 2012

20. The United Daily News Group New Media Lab, "Taiwanese Media under China's Great Firewall," April 2015, http://p.udn.com.tw/upf/newmedia/2015_data/20150327_udnfirewall/udnfirewall/ (accessed on 7 March 2017).

21. Interview with Lee Chih-Te. 
Table 1 - Investments across the Taiwan Strait, 1991-2016

\begin{tabular}{|c|c|c|c|c|c|c|}
\hline \multirow[b]{2}{*}{ Year } & \multicolumn{2}{|c|}{ Taiwan Investments in China } & \multicolumn{2}{|c|}{ China Investments in Taiwan } & \multicolumn{2}{|c|}{$\begin{array}{l}\text { Taiwan Total Outward Investments } \\
\text { (excluding China) }\end{array}$} \\
\hline & Case & Amount & Case & Amount & Case & Amount \\
\hline 1991 & 237 & 174,158 & & & 365 & $1,656,231$ \\
\hline 1992 & 264 & 246,992 & & & 300 & 887,259 \\
\hline 1993 & 1,262 & $1,140,365$ & & & 326 & $1,661,046$ \\
\hline 1994 & 934 & 962,209 & & & 324 & $1,616,844$ \\
\hline 1995 & 490 & $1,092,713$ & & & 339 & $1,356,878$ \\
\hline 1996 & 383 & $1,229,241$ & & & 470 & $2,165,404$ \\
\hline 1997 & 728 & $1,614,542$ & & & 759 & $2,893,826$ \\
\hline 1998 & 641 & $1,519,209$ & & & 896 & $3,296,302$ \\
\hline 1999 & 488 & $1,252,780$ & & & 774 & $3,269,013$ \\
\hline 2000 & 840 & $2,607,142$ & & & 1,391 & $5,077,062$ \\
\hline 2001 & 1,186 & $2,784,147$ & & & 1,387 & $4,391,654$ \\
\hline 2002 & 1,490 & $3,858,757$ & & & 925 & $3,370,046$ \\
\hline 2003 & 1,837 & $4,594,985$ & & & 714 & $3,968,588$ \\
\hline 2004 & 2,000 & $6,939,912$ & & & 658 & $3,382,022$ \\
\hline 2005 & 1,287 & $6,002,029$ & & & 521 & $2,447,449$ \\
\hline 2006 & 897 & $7,375,197$ & & & 478 & $4,315,426$ \\
\hline 2007 & 779 & $9,676,420$ & & & 464 & $6,469,978$ \\
\hline 2008 & 482 & $9,843,355$ & & & 387 & $4,466,491$ \\
\hline 2009 & 249 & $6,058,497$ & 23 & 37,486 & 251 & $3,005,554$ \\
\hline 2010 & 518 & $12,230,146$ & 79 & 94,345 & 247 & $2,823,451$ \\
\hline 2011 & 575 & $13,100,871$ & 105 & 51,625 & 306 & $3,696,827$ \\
\hline 2012 & 454 & $10,924,406$ & 138 & 331,583 & 321 & $8,098,641$ \\
\hline 2013 & 440 & $8,684,904$ & 138 & 349,479 & 373 & $5,232,266$ \\
\hline 2014 & 388 & $9,829,805$ & 136 & 334,631 & 493 & $7,293,683$ \\
\hline 2015 & 321 & $10,398,224$ & 170 & 244,067 & 462 & $10,745,195$ \\
\hline 2016 & 252 & $9,183,992$ & 158 & 247,628 & 496 & $12,123,094$ \\
\hline
\end{tabular}

(Unit: US\$1,000)

Source: The Taiwan Investment Commission (2017)

late 2000s, China's State Council Taiwan Affairs Office and provincial/municipal governments became eager to provide Taiwanese media with embedded advertisements promoting Chinese business and tourism, (22) treating the recipients as their propaganda channels in Taiwan. According to the investigation report of the Control Yuan of Taiwan, though such advertisements were illegal in Taiwan, (23) China Times and UDN still illegally accepted financial resources from Chinese provincial/municipal governments and carried numerous embedded advertisements regarding tourism promotion since 2010 at the latest (Hung, Yang, and Chen 2014, pp. 13-19; Lee 2014, p. 121). (24)

The Want Want Group even established the Want Want-China Times Cultural Media agency in Beijing to subcontract advertising packages from the Chinese authorities to other media firms in Taiwan. As New Talk's investigation report revealed, when the Governor of China's Fujian Province visited Taiwan in March 2012, the Want Want-China Times Media Group cooperated with the propaganda plan of the Fujian Provincial Government and the Amoy Municipal Government, receiving money from both via Want Want-China Times Cultural Media in Beijing, then carrying a series of relevant embedded news items in China Times and its affiliated newspapers throughout the governor's Taiwan visit (Lee 2014, pp. 118-127). (25)

\section{Capital}

The Chinese government also incorporated Taiwanese media companies into the capital market. In particular, it has sought to purchase ownership of Taiwanese media companies with official financial sponsorship. As Boxun revealed in its late-2010 investigation reports, China's State Council Taiwan Affairs Office has prepared a huge amount of capital, at least US\$300 million, with the clearly identified purpose of purchasing stock in Taiwanese media companies such as Television Broadcasts Satellite (TVBS) channels and the UDN Group's affiliated institutions. However, it is suspected that this vast sum was finally di-

22. Interview with Chen Hsiao-yi; Interview with Ni Yen-Yuan; Interview with Ho Jung-hsing; Interview with Su Tzen-ping; Interview with Lee Chih-Te.

23. The Taiwan Legislative Yuan, "The Act Governing Relations between the People of the Taiwan Area and the Mainland Area," 2015, http://lis.ly.gov.tw/lglawc/lglawkm (accessed on 7 March 2017).

24. The Taiwan Control Yuan, "The Correction \# 099教正0022," 11 November 2010, http://www.cy.gov.tw/sp.asp?xdurl=./CyBsBox/CyBsR2.asp\&ctNode=911 (accessed on 7 March 2017); "The United Daily Hired a Reporter for Embedded News in Mainland," China Times, 17 November 2012.

25. Chau-yi Lin, "Fujian Provincial Government's Embedded Advertisements on the China Times," NewTalk, 30 March 2012, http://newtalk.tw/news/view/2012-03-30/23697 (accessed on 7 March 2017). 
verted and transferred to Taiwan, Hong Kong, and other countries before 2007. (26)

The Chinese government also encouraged some Taiwanese capitalists with business interests based in China to purchase ownership of Taiwanese media companies. Take the Want Want Group, for example. Beginning with manufacturing and selling rice crackers in Taiwan, the group started to expand its food business to the Chinese market from 1989, subsequently becoming the largest manufacturer of rice cakes and flavoured milk in China, and investing in hotels, hospitals, insurance, and real estate there. (27) Unexpectedly, the Want Want Group suddenly purchased the China Times in 2008 and further merged with China Television (CTV) and Chung Tien Television (CtiTV) in 2009. In an interview, Tsai Eng-meng denied being the agent sent by Beijing to purchase the China Times Group, but he admitted knowledge that China's State Council Taiwan Affairs Office had tried to commission agents to do so. ${ }^{(28)}$ However, according to a senior Taiwanese government official, China's Taiwan Affairs Office actually cooperated with a senior Kuomintang (KMT) leader to convince Tsai Eng-meng to purchase the group under the direction of the CCP's Publicity Department, to prevent its acquisition by the anti-communist Next Media Group (Hsu 2014, p. 520). After purchasing the China Times in November 2008, Tsai Eng-meng immediately met with Wang Yi, head of China's State Council Taiwan Affairs Office, in December 2008. There, Tsai Eng-meng expressed to Wang Yi that one of his goals in merging with the China Times Group was to "advance the further development of cross-Strait relations with the power of the media." Wang Yi replied that the Taiwan Affairs Office would support the Want Want Group's food and media businesses uncompromisingly. ${ }^{(29)}$

Probably inspired by the experiences of some pro-Beijing capitalists in Hong Kong, some Taiwanese capitalists with business interests based in China considered purchasing media ownership in Taiwan as a strategy to increase their political leverage for receiving investment subsidies and other potential business favours from the Chinese government. (30) For instance, after merging with the China Times Group, the Want Want Group received numerous embedded advertising fees from the Chinese authorities and its Chinese subsidiary company, Want Want China Holdings Limited, also received US\$47 million in Chinese official subsidies in 2011, which accounted for $11.3 \%$ of its total net profit. (31) Moreover, the Want Want Group has been striving for special benefits from the Chinese government through its media influence. For example, when the State Council of China issued Document Number 62 in November 2014, which aimed to cancel and recover all tax preferences offered by local governments to foreign investors without the central government's prior approval, the Want Want Group cooperated with Taiwan's six major industrial and commercial associations, Taiwanese businesses associations in China, and the Taiwanese government-sponsored Straits Exchange Foundation to request reservation of, or at least compensation for, the tax preferences previously approved for Taiwanese businesses. In particular, the Want Want Group held forums for Taiwanese businesses during April 2015 and produced extensive relevant coverage via its print and electronic media. In response, the State Council of China decided to restore all the favours local governments had already offered and already agreed to offer to Taiwanese businesses in May 2015.

Furthermore, probably encouraged by Tsai becoming closer to the Chinese authorities after purchasing the China Times Group, some Taiwanese capitalists started to engage in the Taiwanese media sector with the expectation of obtaining potential interests for their enterprises in China (Cook 2013, p. 9; Hsu 2014, p. 534). For instance, the Ting Hsin Group, the largest instant noodle producer in China, acquired China Network Systems in Taiwan in August 2014. Similarly, Wang Cher, president of the High-Tech Computer Corporation (HTC) (a mobile phone company largely basing its manufacturing and sales in China), purchased a considerable percentage of the stocks of the TVBS Media Group in June 2011, later gaining full control over the group in January 2015. Taken together, following the example of Hong Kong capitalists and Tsai Eng-meng, a trend appeared of using media ownership in Taiwan as an instrument for fighting for corporate interests in China.

\section{Routinizing external-oriented self- censorship in Taiwan}

Embedded in the Chinese circulation, advertising, and capital markets, many Taiwanese media companies, regardless of their positions on the unification-independence issue, had incentives to accommodate the corporate and market structures of the media to Beijing's rules on mass communication. Such structural changes, in turn, facilitated and even routinized Taiwanese media's self-censorship and subsequent news biases favouring the Chinese authorities.

Regarding financial structure, many Taiwanese media companies relied increasingly on their financial resources in China, especially after the key aforementioned developments in 2008 and 2011 (Chung 2012, pp. 67-70). FTV and SET, among others, strove for opportunities to sell copyrights and broadcast TV programs in the Chinese market. Conversely, the Want WantChina Times Media Group and UDN, for example, received subscriptions, advertising fees, and some other special benefits from the Chinese authorities. The Want Want Group even accepted subsidies from the Chinese government.

Regarding organisational structure, the editorial department was increasingly pressed to cooperate with the media owner, business department, or programming department, with editorial independence partly restrained and self-censorship exercised regarding Chinese sensitive topics to ensure the continuation of financial resources coming from China. In the Want Want-China Times Media Group, the staff and businesses devoted to crossStrait affairs at the China Times were even moved from the political division to the mainland centre within two years of the 2008 merger, as news reports about China and cross-Strait relations came under direct control of the new owner and high-level managers. ${ }^{(32)}$ In addition, a new newspaper

26. Boxun,"The Beijing Municipal Public Security Bureau Forestalled the Central Discipline Inspection Commission to Intervene in the Taiwan Affairs Office for the 300 Million USD Unaccounted for," Boxun News Website, 19 December 2010, https://www.boxun.com/news/gb/china/2010/ 12/201012191327.shtml (accessed on 7 March 2017).

27. Brain Magazine, "How Did the China Times Lose Its Throne?," Brain Magazine, December 2008; Andrew Higgins, "Tycoon Prods Taiwan Closer to China," The Washington Post, 21 January 2012, https://www.washingtonpost.com/world/asia_pacific/tycoon-prods-taiwan-closer-tochina/2012/01/20/glQAhswmFQ_story.html (accessed on 7 March 2017).

28. Hsi-ju Tien, "'Taiwanese People Are Not DegradedWhen Becoming Chinese People'Tsai Eng-Meng: The Taiwan Affairs Office Did Send Someone to Buy the China Times, But Not Me.," Wealth Magazine, April 2009.

29. Xing-Fei Lin, "Sir, We Purchased the China Times Group!," CommonWealth Magazine, 25 February 2009 .

30. Interview with Chen Hsiao-yi; Interview with Su Tzen-ping

31. Fathom China, "In Profile Subsidies: Public Funds for Private Firms," in GK Dragnomics Corporate Analysis, 2013; "Perverse Advantage," The Economist, 27 April 2013, http://www.economist.com/ news/finance-and-economics/21576680-new-book-lays-out-scale-chinas-industrial-subsidiesperverse-advantage (accessed on 7 March 2017).

32. Interview with Huang Jhe-Bin, former senior news reporter and editor of the China Times, Taipei, 16 June 2014; Interview with Anonymous Interviewee, senior editor of the China Times, Taipei, 14 July 2014. 
named Want Daily was also established by the group in August 2009 to focus on providing Chinese and cross-Strait information and improving mutual understanding between China and Taiwan.

In the news editing process, there were generally two patterns of self-censorship: first, top-down, in which the owner explicitly or implicitly delivered his ideas about news editing and reporting to the chief editor, the chief editorial writers, and other high-level managers through weekly executive meetings or other informal communications; and second, bottom-up, in which reporters and editors tried to discern the owner's ideas themselves and then slanted news and opinion content to cater to the owner. Initially, the functioning of either pattern was largely based on the owner holding the highest power to decide on employee retention and promotion. (33) However, through a daily process of socialisation in the corporate hierarchy, this self-censorship became a culture that reporters and editors grew accustomed to, took for granted, and finally complied with as a matter of course (Kawakami 2015, p. 19).

With these corporate structures adjusted, the media content of many Taiwanese news organisations was partially slanted in favour of the Chinese authorities. Such news biases occurred especially in media firms already embedded in the Chinese market, rather than those not yet there. For instance, Tsai Eng-meng was suspected of increasing editorial pressure to whitewash content regarding the Tiananmen Incident, Tibet independence, Xinjiang autonomy, and Falun Gong in both the news and opinion pages of the China Times, ${ }^{(34)}$ however, he encouraged coverage of the bright side of China, which contributed to mutual understanding and harmonious development across the Taiwan Strait. ${ }^{(35)}$ According to Chang Chin-Hwa's research, China Times and UDN, as newspapers accepting embedded advertisements from the Chinese authorities, tended to employ a more detailed, positive approach to reporting news about Chinese leaders and their official visits to Taiwan, compared to the two other major newspapers (i.e., Apple Daily and Liberty Times) (Chang Chin-Hwa 2011; Hung, Yang, and Chen 2014). Similarly, when covering the Xinjiang conflicts, China Times and UDN, compared to their two major rivals in Taiwan, also clearly tended to conform to the "China official frame." In particular, 100\% and $77.78 \%$ of the related reports in China Times and UDN were based exclusively on Chinese official news sources. Moreover, $100 \%$ and $83.33 \%$ of the news reports in China Times and UDN ascribed responsibility for the conflicts completely to the protesters, rather than the regime. Moreover, both newspapers failed to include a diverse view of human rights in news reports on these conflicts: in particular, state violations of human rights such as liberty, due process of law, and ethnic autonomy were rarely mentioned (Chang ChinHwa 2015). The situation was even worse on the opinion pages. The China Times's opinion page, traditionally regarded as a liberal sphere for public discussion, is now considered a "mouthpiece of the Chinese government" that has become increasingly obvious in its promotion of China's official viewpoints, defence of the images of Beijing and its incumbents, and even refutation of the Taiwanese majority's perspectives. ${ }^{(36)}$

A similar phenomena occurred in the pro-Taiwanese identity media. According to a SET senior news editor, in response to Beijing's warning to refuse the broadcasting of its drama in China, the SET management established an implicit principle of news reporting to its news department in 2008 to reduce reports about the Tiananmen Incident, Tibet independence, and Falun Gong. ${ }^{(37)}$ An academic report found that SET has presented fewer pieces of news on Tiananmen every year, starting from 2010 at the latest (Hung, Yang, and Chen 2014, pp. 19-23).
Concerning market structure, the expansion of pro-Beijing capitalists in media ownership reinforced the trend of media conglomeration and crossmedia convergence in Taiwan. In particular, having purchased China Times in 2008, and merged with CTV and CtiTV in 2009, the Want Want Group further proposed to acquire China Network Systems in 2011. Although this proposal was ultimately rejected by Taiwan's National Communications Commission in 2013 , the group still successfully grew into a cross-media conglomerate. Such merger and acquisition actions were considered by many as a threat to the diversity of news and opinions offered to the Taiwanese public. ${ }^{(38)}$ For instance, when the Want Want Group's proposal to merge with China Network Systems provoked a large-scale anti-media monopoly demonstration in Taiwan on 31 July 2012, most cable television stations failed to report it for fear of offending such a large media conglomerate (Chung 2012, pp. 8184). The public's concerns about media concentration and news biases, in turn, induced the formulation of anti-media monopoly legislation from January 2013, which remains in progress at present.

\section{Conclusion}

This paper proposes a theoretical framework to systematise how the Chinese government extends its influence on extra-jurisdictional media. It argues that a media company outside China will exercise self-censorship on topics considered sensitive in China when it becomes commercially tied with the Chinese market. With archival and interview data gathered in Taiwan, a case study based on the method of process tracing was conducted on the Want Want-China Times Media Group, UDN, FTV, and SET, among other Taiwanese media companies. The case study basically supports the proposed theory.

The findings are summarised as follows. First, at the international level, as a rising regional hegemon, China was eager to make Taiwan economically dependent to facilitate directing its hegemonic and unification propaganda towards Taiwan. Second, at the sectoral level, due to Taiwan's increasing economic dependence on China, the Chinese government had more opportunities to co-opt Taiwanese media capitalists as its local collaborators in Taiwan, offering them financial interests in the Chinese circulation, advertising, and capital markets. Such financial co-optation worked upon both pro-Chinese unification and pro-Taiwanese identity media in Taiwan. Third, at the corporate level, the Chinese government, assisted by Taiwanese media capitalists, implemented and even routinized self-censorship on Chinese sensitive topics by urging Taiwanese media companies to adjust their corporate and market structures to accommodate Beijing's mass communication policies. Through these three steps, the Chinese government succeeded in "outsourcing" its censorship to private media companies in Taiwan.

33. Interview with NiYen-Yuan; interview with Wang Chien-chuang, former chief editor and president of the China Times, Taipei, 24 July 2014.

34. Interview with Tsai Chi-Ta, former senior opinion editor of the China Times, Taipei, 17 June 2014; interview with Ni Yen-Yuan; interview with Wang Chien-chuang.

35. Interview with Yo Wan-chi, former news reporter of the China Times, Taipei, 22 May 2014; interview with Anonymous Interviewee, senior manager of the Want Want-China Times Group, Taipei, 13 June 2014.

36. Interview with Tsai Chi-Ta; interview with Wang Chien-chuang.

37. Interview with Anonymous Interviewee, senior editor of SET, 30 July 2014.

38. The Taiwan Legislative Yuan, "The Market Share Rate of The Want Want-China Times Group and the China Network Systems," The Legislative Yuan Gazette, Vol. 100, No. 74, November 2011, p. 252; Hui-Lin Lin, Lihyun Lin, Chen-Ling Hung, Chinhwa Chang, Kuo-Chang Huang, and Show-Ling Jang, "12 Reasons for Rejecting Media Monster!" Center for Public Policy and Law of National Taiwan University, 2012, pp. 4-6. 
This paper has several implications. First, it resonates with Kurlantzick and Link's model of the "commercialisation of censorship," as well as Wu Jiehmin's model of the "China factor" influence mechanism. By integrating the two models into a theoretical framework, this paper extends the "commercialisation of censorship" beyond China to the international level, and applies the "China factor" model to Taiwan's mass media. The proposed theoretical framework is therefore potentially applicable to other countries whose media may suffer from censorship diffused from China.

Second, the paper's findings are not only relevant to Taiwan but may also apply to many other countries that have been or will be subject to China's economic influence. Given the current trend of China's economic rise, concerns are increasing regarding China's potential impact on human rights and democracy in its neighbouring countries and even globally (Link 2002; Diamond 2009; Kurlantzick and Link 2009; Ambrosio 2010; Wu 2012; Kurlantzick 2013; Pillsbury 2015; Nathan 2015). If this impact does transpire, Taiwan, as the country in which China's interest is most intense, is most likely to be the first affected. Therefore, the paper's value may move beyond Taiwan by applying it to many other countries whose levels of media freedom are likely to suffer through increasing economic linkages with China.

Finally, for liberal states around China, one policy implication may be to design institutions to protect the media from inappropriate intervention of not only state power and market forces domestically but also political and economic forces from abroad. For instance, while Taiwan's media stopped receiving embedded advertisements from the Taiwanese government from 2011 onward, some continued receiving embedded advertisements from the Chinese authorities via subcontracts with Taiwanese businesses. It seems necessary for liberal states to establish more effective institutions to withstand external political intervention in the media through economic activities.

I Huang Jaw-Nian is Assistant Professor at the Graduate Institute of China Studies, Tamkang University.

Graduate Institute of China Studies, Tamkang University, No.151

Yingzhuan Rd., Tamsui Dist., New Taipei City 25137, Taiwan

(jnhuang@mail.tku.edu.tw).

Article received on 6 December 2016. Accepted on 16 March 2017.

\footnotetext{
References

AMBROSIO, Thomas. 2010. "Constructing a Framework of Authoritarian Diffusion: Concepts, Dynamics, and Future Research." International Studies Perspectives 11(4): 375-92.

CHANG, Chin-Hwa. 2011. "Analysis of the News Placement and Coverage of Three Chinese Buying Groups by Taiwan's Four Main Newspapers from the Perspective of van Dijk's Discourse and Manipulation Theory." Chinese Journal of Communication Research 20: 65-93.

CHANG, Chin-Hwa. 2015. "How Different Newspapers Cover Xingjian Conflicts from Human Right Perspective? A Frame Analysis of 10 Newspapers from Taiwan, Hong Kong, Mainland China, Britain and Unites States." Mass Communication Research 125: 1-47.

CHANG, Mau-Kuei. 2011. "Advocating of the Perspective of 'China Impact Studies'." Taiwanese Sociological Association Communication 72: 25-30.

CHEN, Ping-Hung. 2006. "Market Entry Modes and Determinants of Taiwanese Media Firms into Mainland China." Mass Communication Research 89.
}

CHUNG, Nien-huang. 2012. My Life Experience in the Big Talk News. Taipei:Avanguard.

COOK, Sarah. 2013. The Long Shadow of Chinese Censorship: How the Communist Party's Media Restrictions Affect News Outlets Around the World. Washington, DC:The Center for International Media Assistance, National Endowment for Democracy.

DIAMOND, Larry. 2009. "The Shape of Global Democracy." Brown Journal of World Affairs 15(2): 77-86.

GAT, Azar. 2007. "The Return of Authoritarian Great Powers." Foreign Affairs 86: 59-69.

GEORGE, Alexander L., and Andrew BENNETT. 2005. Case Studies and Theory Development in the Social Sciences. Cambridge, MA: Harvard Kennedy School. 205-232.

HSU, Chien-Jung. 2014. "China's Influence on Taiwan's Media." Asian Survey 54(3): 515-39.

HUNG, Yao-nan, Hsiu-Jing YANG, and Chun-Wei CHEN. 2014. How Did China Factor Influence Taiwanese Media?Taipei: Graduate Institute of National Development, National Taiwan University.

KAWAKAMI, Momoko. 2015. "Political Permeation under the Market Mechanism: The Mechanisms of China's Influence in the Taiwanese Media Industry." Taiwanese Sociological Association Communication 83: 17-20.

KURLANTZICK, Joshua, and Perry LINK. 2009. "China: Resilient, Sophisticated Authoritarianism." in Christopher Walker (ed.), Undermining Democracy: 21 st Century Authoritarians. Washington, DC: Freedom House. 13-28.

KURLANTZICK, Joshua. 2013. Democracy in Retreat: The Revolt of the Middle Class and the Worldwide Decline of Representative Government. New Haven, Conn. and London: Yale University Press.

LEE, Chih-Te. 2014. Journey Without Destination. New Taipei: Gusa.

LINK, Perry. 2002. "The Anaconda in the Chandelier: Chinese Censorship Today." The New York Review of Books April 11.

MA, Ngok. 2007. "State-Press Relationship in Post-1997 Hong Kong: Constant Negotiation Amidst Self-Restraint." The China Quarterly 192: 949-970.

NATHAN, Andrew J. 2015. "China's Challenge." Journal of Democracy 26(1): 15670.

PILLSBURY, Michael. 2015. The Hundred-Year Marathon: China's Secret Strategy to Replace America as the Global Superpower. New York: Henry Holt and Co.

SARTORI, Giovanni. 1970. "Concept Misformation in Comparative Politics," The American Political Science Review 64(4): 1033-1053.

SCIUTTO, James E. 1996. "China's Muffling of the Hong Kong Media." Annals of the American Academy of Political and Social Science 547: 131-43.

SHIAU, Chyuan-jenq. 2004. "On the 'Peaceful Rise' of China." Political Science Review 22.

TUNG, Chen-Yuan. 2011. "The Cross-Strait Economic Cooperation Framework Agreement: Controversy and Effects." Journal of National Development Studies 11(1).

WU, Jieh-min. 2012. The Third View of China. Taipei: Taiwan, Rive Gauche.

WU, Jieh-min. 2015. "The China Factor and Its Local Collaboration Mechanisms: An Analytical Framework." Taiwanese Sociological Association Communication 83: $5-8$.

WU, Jieh-min. 2016. "The China Factor in Taiwan: Impact and Response." in Gunter Schubert (ed.), Handbook of Modern Taiwan Politics and Society. New York, NY: Routledge. 425-45. 